\title{
DIRASAH
}

Volume 2, Number 1, February 2019

p-ISSN: 2615-0212 | e-ISSN: 2621-2838

https://ejournal.iaifa.ac.id/index.php/dirasah

\begin{tabular}{|c|c|c|}
\hline Accepted: & Revised: & Published: \\
Desember 2018 & Januari 2019 & Februari 2019 \\
\hline
\end{tabular}

\section{Sistem Pembelajaran Majelis Taklim Padhang Mbulan dalam Mewujudkan Learning Society (Studi Majelis Ilmu Maiyah Padhang Mbulan Jombang)}

\author{
Moh. Syafi'il Anam \\ Institut Agama Islam Diponegoro Nganjuk, Indonesia \\ e-mail:m.syafiilanam@gmail.com
}

\begin{abstract}
There is a unique phenomenon in Jombang (Indonesia). The uniqueness of one of them is a society that is set in heterogeneous gathering of religious activities from night to early morning in the form of assembly Takim Maiyah Padang Mbulan. In this study, will be discussed about the learning system of the Assembly of Padhang Mbulan in realizing the Learning Society. This study used a qualitative approach with this type of case study research. The results showed that the Majelis Ilmi Maiyah Padhang Mbulan has its own learning system with its style, with the aim of deepening the tawheed and getting closer to Allah SWT. Learning methods in the form of interactive and communicative lectures with jokes or humor, deconstruction methods-reconstruction of values, questions and answers and discussion, free and open stage, analogy with the language of culture, demonstrations and methods The musical using the human media itself was assisted by other secondary media such as the utilization of various musical instruments both traditional and modern. The Learning society in the Assemblyman's assembly of Padhang Mbulan can be classified into three related phases i.e. input, process and output. Input in the form of public awareness (Jama'ah Maiyah) in learning and seeking knowledge. The process of entry intensity in attendance at the forum Maiyah. Output the form of works or programs produced Jama'ah Maiyah.
\end{abstract}

Keywords: Learning System, Assembly Taklim Padhang Mbulan, Learning Society. 


\section{Pendahuluan}

Di era globalisasi ${ }^{1}$ ini, salah satu kegiatan pendidikan dan kelompok belajar yang berbasis masyarakat di Indonesia, saat ini sedang tumbuh dan semakin berkembang yakni lembaga pengajian atau pendidikan Islam yang disebut dengan Majelis Taklim. ${ }^{2}$ Majelis Taklim sebagai institusi pendidikan Islam yang berbasis masyarakat peran strategisnya terutama terletak dalam mewujudkan learning society (masyarakat belajar), yakni suatu masyarakat yang memiliki tradisi belajar tanpa di batasi oleh usia, jenis kelamin, tingkat pendidikan, dan dapat menjadi wahana belajar, serta menyampaikan pesanpesan keagamaan, wadah mengembangkan silaturrahmi dan berbagai kegiatan kegamaan lainnya, bagi semua lapisan masyarakat. ${ }^{3}$

Urgensi Majelis Taklim yang demikian itulah, yang menjadi spirit diintegrasikannya majlis taklim sebagai bagian penting dari Sistem Pendidikan Nasional, sebagaimana dituangkan dalam Undang-undang Republik Indonesia nomor 20 tahun 2003 Bab VI pasal 26 ayat 1 yang di nyatakan pemerintah bahwa, "pendidikan non formal diselenggarakan bagi warga masyarakat yang memerlukan layanan pendidikan yang berfungsi sebagai pengganti, penambah, dan atau pelengkap pendidikan formal dalam rangka mendukung pendidikan sepanjang hayat". ${ }^{4}$ Bahkan pada ayat 4 juga secara eksplisit disebutkan; "Satuan pendidikan non formal terdiri atas lembaga kursus, lembaga pelatihan, kelompok

\footnotetext{
${ }^{1}$ Menurut Cak Nun, Globalisasi ditandai dengan terasa semakin sempitnya dunia, dan terasa semakin cepatnya waktu, hal ini mengandung muatan-muatan yang begitu signifikan, seperti metabolisme kekuasaan dunia, ketergantungan ekonomi, transformasi nilai-nilai, modifikasi ideologi menjadi semacam ideologi baru atau mungkin melangka ke -sebutlah transideologi. Lihat Emha Ainun Nadjib, Surat Kepada Kanjeng Nabi (Bandung, Mizan: 1998), 329.

${ }^{2}$ Meskipun kata majelis ta'lim berasal dari bahasa Arab, tetapi istilah ini sendiri tidak digunakan oleh negara atau masyarakat Arab. Istilah dan penamaan majelis ta'lim lebih banyak ditemukan di Jakarta, Khususnya di kalangan masyarakat Betawi sementara di daerah-daerah lain lebih dikenal dengan Pengajian agama Islam. Dewan Redaksi, Ensiklopedi Islam (Jakarta: Ichtiar Baru Van Hoeven, 2001), 120.

${ }^{3}$ Pengertian learning society secara harfiah diambil dari bahasa Inggris yang berarti masyarakat belajar. Learning society adalah memberdayakan peran masyarakat dan keluarga dalam kegiatan pendidikan. Diharapkan masyarakat dan keluarga berperan aktif dalam hal belajar. Tentulah jika masyarakat dan keluarga telah aktif untuk gemar belajar maka akan terbentuk bangsa yang rajin belajar. Selengkapnya lihat al-Rasyidin dan Samsul Nizar, Filsafat Pendidikan Islam: Pendekatan Historis, Teoritis dan Praktis (Jakarta: Ciputat Press, 2005), 177.

${ }^{4}$ Undang-Undang Republik Indonesia Nomor 14 Tahun 2005 Tentang Guru \& Dosen Serta Undang-Undang Republik Indonesia Nomor 20 Tahun 2003 Tentang Sistem Pendidikan Nasional, (Bandung: Cira Umbara, 2006), 86.
}

Dirasah, Vol. 2, No. 1, Februari 2019 
belajar, pusat kegiatan belajar masyarakat dan Majelis Taklim, serta satuan pendidikan yang sejenis". 5 Sebagai institusi pendidikan Islam non formal, Majelis Taklim dilihat dari karakteristiknya secara umum adalah lembaga (institusi) yang melaksanakan pendidikan, atau pengajian agama Islam, memiliki kurikulum, Kiai atau guru, jama'ah, metode, materi dan tujuan pembelajaran (sistem pembelajaran). ${ }^{6}$

Setidaknya dalam dua dasawarsa terakhir, konsep dan sistem pembelajaran seperti ini juga dilaksanakan oleh komunitas belajar yang bernama Majlis Ilmu Maiyah $^{7}$ yang terdapat di beberapa titik daerah -hampir menyeluruh nusantara. Diantaranya adalah Maiyah Padhang Mbulan yang merupakan induk atau embrio maiyah se-nusantara (Jombang Jawa Timur), Mocopat Syafaat (Yogyakarta), Kenduri Cinta (Jakarta), Gambang Syafaat (Semarang), Bangbang Wetan (Surabaya), Obor Ilahi (Malang), Paparadhang Atie (Sulawesi) dan lain sebagainya. ${ }^{8}$ Forum-forum tersebut merupakan asuhan dari sosok masyhur Emha

\footnotetext{
${ }^{5}$ Ibid, 87.

${ }^{6}$ Dewan Redaksi, Ensiklopedi Islam (Jakarta: Ichtiar Baru Van Hoeven, 2001), 120-121.

${ }^{7}$ Maiyah sebagai suatu komunitas mempunyai cerita dan latar belakang tersendiri untuk diurai asal-usulnya dan sudah pasti akan ada bab tersendiri untuk itu, tetapi yang jelas komunitas ini terbentuk oleh rasa kebersamaan akan nilai, norma, cita-cita dan pengalaman yang dimiliki bersama diantara penggeraknya. Dari nilai-nilai dan norma informal yang lahir atas kebersamaan itu pada akhirnya melahirkan sesuatu yang kita kenal sebagai social capital. Secara subtantif, hal-hal yang bersangkutan dengan nilai-nilai moral dan mental seperti halnya kejujuran, loyalitas, saling berbagi dan kekuatan komitmen menjadi menu utama dari semangat Maiyah. Kalau boleh meminjam istilah civil society yang ditarik pada wilayah cita-cita Maiyah, harapan itu bisa ditafsir sebagai sebuah keluarga dan negara yang menjadi satu kesatuan yang sehat dalam suatu tatanan masyarakat, kalau kita sepakat dengan penegakan sebuah demokrasi. Artinya, Maiyah pada dasar terbentuknya adalah adanya kebersamaan untuk saling menyapa, saling support dan saling sambung menyambung untuk bersama membuat pola kekuatan yang pada akhirnya menjadi kekuatan yang ter-distribusi diantara komponen masyarakat, yang (merasa) diabaikan oleh kekuatan sistem (negara) yang ada dalam level apapun. Di lain sisi, kekuatan civil society pada nadi Maiyah berupaya untuk tidak ikut merepotkan kekuatan sistem formal, bahkan kalau mungkin dapat memperkuat tatanan sebuah sistem itu sendiri. Maiyah adalah satu mahluk yang bisa dikatakan absurd keberadaannya, dia bukan partai politik, bukan ormas, bukan persatuan ini atau itu, yang kongkrit jumlah jamaah atau pelingkarnya, yang anggotanya kemana-mana membawa kartu tanda keanggotaan layaknya organisasi NU atau Muhammadiyah atau lainnya. Baca Andsisko, "Maiyah dan Ruang-Ruang Jejaring", dalam http://www.Maiyah.net/2012/04/Maiyah-dan-ruang-ruang-jejaring.html, diakses 05 Juni 2013.

${ }^{8}$ Emha Ainun Nadjib, Kiai Bejo, Kiai Untung, Kiai Hoki (Jakarta: Kompas, 2007), 257.
} 
Ainun Nadjib ${ }^{9}$, yang mempunyai akronim Cak Nun ${ }^{10}$, EAN, CN, Mbah Nun, dan lain sebagainya.

Kegiatan keagamaan yang berbasis masyarakat tersebut menarik untuk dikaji dan dilakukan penelitian mendalam karena mempunyai dampak signifikan terhadap pendidikan Islam kaitannya dengan terbentuknya masyarakat pembelajar atau learning society. Dalam penelitian ini, penulis membatasi pembahasan -karena banyaknya forum maiyah - pada sistem pembelajaran Majelis Ilmu Maiyah di Jombang Jawa Timur, yakni Maiyah Padhang Mbulan dan keterkaitannya dalam mewujudkan learning society (masyarakat belajar). Hal tersebut setidaknya didasarkan pada reason d'etre sebagai berikut:

Pertama, Maiyah Padhang Mbulan Jombang sebagai salah satu jenis dari Majelis Taklim dengan karakter distingtifnya merupakan induk atau embrio lahirnya maiyah nusantara. Menurut Prayogi R. Saputra, "Pada pengajian edisi pertama di Jombang, jumlah jama'ah yang hadir hanya 40 orang. Bulan kedua 270 orang. Bulang ketiga 500-an orang. Dan terus berkembang hingga pernah mencapai 35.000 orang". 11 Terjadinya peningkatan kuntitas jama'ah tersebut menarik untuk dikaji apa sebenarnya yang menjadi bergainning power bagi masyarakat awam dalam mengikuti kegiatan tersebut.

Kedua, dalam rangka mengungkap apa dan bagaimana sistem pembelajaran yang digunakan dalam maiyahan Padhang Mbulan, karena acara tersebut berlangsung cukup lama hingga kurang lebih 7 jam dan jama'ah Maiyah sangat bergembira dan menikmati maiyahan tersebut. ${ }^{12}$ Dengan alokasi waktu

9 Nama aslinya adalah Muhammad Ainun Nadjib, akrab dipanggil Cak Nun dilahirkan di Menturo, Sumobito, Jombang, Jawa Timur pada Rabu Legi 27 Mei 1953 sebagai putra keempat dari 15 bersaudara, dari suami istri H.A. Lathif dan Halimah. Cak Nun yang ketika masih muda dipanggil Ainun dibesarkan orang tuanya yang sibuk oleh urusan madrasah, langgar, dan berbagai kegiatan sosial dengan penduduk di dusunnya. Baca Jabrohim, Tahajjud Cinta Emha Ainun Nadjib Sebuah Kajian Sosiologi Sastra (Yogyakarta: Pustaka Pelajar, 2003), 27.

${ }^{10}$ Kata "Cak" adalah bahasa panggilan keseharian di pakai untuk menghormati orang yang punya kelebihan, baik dari segi umur atau ilmu. Sebutan ini biasa di pakai orang Jawa bagian timur yang dalam arti lain berarti "kakak" laki-laki.

${ }^{11}$ Lihat Prayogi R. Saputra, Spiritual Jourey; Pemikiran \& Permenungan Emha Ainun Nadjib (Jakarta: Kompas, 2012), 73.

${ }^{12}$ Menurut Prayogi, Maiyahan dimulai pukul 20.00 hingga 03.00 dini hari. Artinya para jama'ah hadir sebelum pukul 20.00. Suplemen apa yang ampuh untuk mengikat orang duduk selama itu tanpa fasilitas yang memadai? Duduk di terpal atau maksima tikar, tidak ada makanan atau minuman yang disuguhkan. Kalau hujan turun, mereka akan kehujanan. Banyak yang bertanya daya tahan apa sebenarnya yang demikian itu? Harus ada intervensi energi yang memiliki kekuatan untuk melipat waktu dan menggembirakan hati secara luar biasa. Yang menurut

Dirasah, Vol. 2, No. 1, Februari 2019 
kegiatan yang sedemikian panjang tersebut, menjadi semakin menarik untuk dilakukan penelitian lebih lanjut tentang apa sebenarnya yang menjadi isi kegiatan maiyah tersebut.

Berikut adalah replikasi dari suasana kegiatan maiyah Padhang Mbulan yang dilaksanakan setiap satu bulan sekali di desa Menturo. Dimana jama'ah yang terdiri lapisan masyarakat berkumpul membentuk lingkaran maiyah.

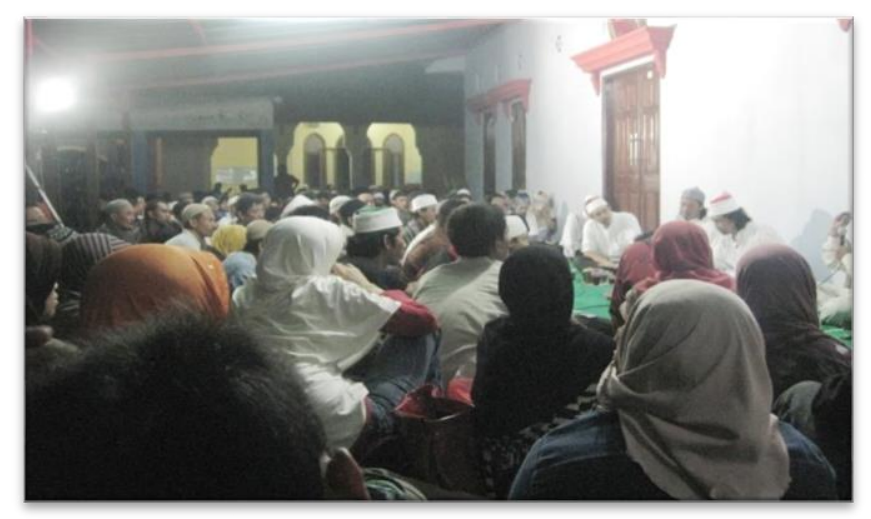

Gambar Suasana Maiyah Padhang Mbulan (Lingkaran Maiyah) Dok. Peneliti, Juni 2013

Ketiga, antusiasme masyarakat dalam mengikuti majelis ilmu Padhang Mbulan. Jama'ah yang hadir pada forum tersebut tidak hanya dari warga desa Menturo sendiri, namun juga masyarakat luar Jombang juga datang dan mengikuti kegiatan pengajian Padhang Mbulan tersebut hingga selesai. Masyarakat yang hadir dalam forum maiyah PB (akronim dari Padhang Mbulan) tersebut bisa disebut jama'ah atau masyarakat heterogen dari latar belakang dan status yang berbeda-beda. ${ }^{13}$ Fenomena Padhang Mbulan yang dihadiri oleh masyarakat yang heterogen tersebut merepresentasikan suasana learning society dengan antusiasme individu-individu yang berkumpul bersama-sama dalam pembelajaran majelis ilmu Padhang Mbulan.

\footnotetext{
Anand Krisna menyebutnya ada cahaya kharisma yang menarik orang-orang untuk bertahan. Lihat Prayogi R. Saputra, Spiritual Jourey., 79.

${ }^{13}$ Hal tersebut diperoleh dari hasil observasi pra penelitian dan wawancara kepada jama'ah maiyah yang diakukan penulis sejak datang ke lokasi diadakannya pengajian atau majelis ilmu Padhang Mbulan pada Bulan Juni 2013.
} 
Berdasarkan beberapa alasan di atas, langsung ataupun tidak langsung, secara sistematik asumsi futurologist dan konsep pembelajaran Majelis Ilmu Maiyah Padhang Mbulan tersebut akan berpengaruh terhadap strategi pengembangan dan karakteristik komponen-komponen sub sistem pendidikan luar sekolah dalam mewujudkan masyarakat belajar (learning society). Maka, dalam penelitian ini mengambil tema "Sistem Pembelajaran Majelis Taklim Padhang Mbulan dalam Mewujudkan Learning Society; Studi Majelis Ilmu Maiyah Padhang Mbulan Jombang Jawa Timur". Tujuan penelitian ini adalah mendeskripsikan sistem pembelajaran dan Learning Society Majelis Taklim Maiyah Padhang Mbulan Jombang Jawa Timur .

\section{Metode Penelitian}

Penelitian ini menggunakan pendekatan kualitatif dan jenis penelitian studi kasus. Dengan setting lokasi penelitian di Majelis Ilmu Maiyah Padhang Mbulan yang terletak di Desa Menturo Kecamatan Sumobito Kabupaten Jombang Jawa Timur. Dalam penelitian ini, yang merupakan data kualitatif adalah hasil wawancara terbuka kepada pengasuh, narasumber dan jama'ah maiyah, deskripsi dokumen maiyah Padhang Mbulan dan pengamatan atau observasi sistem pembelajaran majelis ilmu maiyah dan lain-lainnya. Untuk mengetahui pelaksanaan sistem pembelajaran majelis ilmu Padhang Mbulan dan learning society, peneliti memilih informan yakni Pengasuh, narasumber dan jama'ah maiyah.

Prosedur pengumpulan data dalam penelitian ini menggunakan beberapa teknik yang sering digunakan dalam penelitian kualitatif, yaitu observasi partisipan, wawancara dan dokumentasi. Menurut Marshall dan Rossman dalam Sugiono menyatakan bahwa ketiganya merupakan teknik yang sangat fundamental dalam penelitian kualitatif. ${ }^{14}$ Pemanfaatan teknik wawancara dilakukan untuk mendapatkan keterangan pelaksanaan sistem pembelajaran Majelis ilmu Padhang Mbulan. Sedangkan pemanfaatan teknik dokumentasi dilakukan untuk menelusuri deskripsi dokumen aktivitas maiyah Padhang Mbulan dan lain-lainnya.

Analisis data dilakukan selama dan setelah pengumpulan data. Pada analisis data sebelum penelitian berlangsung, peneliti mencoba untuk mencari

14 Sugiyono, Metode Penelitian Kuantitatif, Kualitatif Dan Research \& Developmental, (Bandung : Alfabeta, 2009), 225.

Dirasah, Vol. 2, No. 1, Februari 2019 
kesesuaian antara keunikan setting lokasi penelitian dengan kajian teori yang ada melalui studi pendahuluan. Untuk analisis data di lapangan, peneliti menggunakan model analisis kualitatif Miles \& Huberman ${ }^{15}$ dengan langkahlangkah sebagai berikut: (1) data reduction (merangkum data); (2) data display (menampilkan data); (3) conclusion (pengambilan kesimpulan).

Dalam rangka memperoleh kesimpulan yang tepat dan objektif, diperlukan kredibilitas data. Kredibilitas data dimaksudkan untuk membuktikan bahwa apa yang berhasil dikumpulkan sesuai dangan apa yang ada dalam latar penelitian yang ada. Untuk memenuhi keabsahan data tentang "Sistem Pembelajaran Majelis Taklim Padhang Mbulan dalam mewujudkan Learning Society", peneliti melakukan pengecekan keabsahan data dengan menggunakan beberapa metode yang memungkinkan dilakukan oleh peneliti. Metode yang digunakan adalah sebagai berikut: (1) perpanjangan keikutsertaan; (2) ketekunan pengamatan; (3) triangulasi.

\section{Pembahasan}

Pada bagian ini, peneliti akan paparkan pembahasan dari temuan penelitian dengan landasan teori tentang "Sistem Pembelajaran Majelis Taklim Padhang Mbulan dalam Mewujudkan Learning Society" yang dilakukan di Majelis Ilmi Maiyah Padhang Mbulan Desa Menturo Jombang Jawa Timur.

\section{Sistem pembelajaran majelis taklim padhang mbulan}

1. tujuan pembelajaran

Komponen sistem pembelajaran pertama yang dibahas dalam bagian ini adalah tentang apa sebenarnya tujuan pembelajaran dari majelis ilmi Maiyah Padhang Mbulan. Menurut Wina Sanjaya, dalam rangka mencapai kualitas pendidikan sebuah lembaga atau organisasi harus memiliki pendekatan sebuah sistem pembelajaran, yang muaranya adalah pencapaian dari tujuan. ${ }^{16}$

\footnotetext{
${ }^{15}$ Matthew B. Miles \& A. Michael Huberman, Analisis Data Kualitatif: Buku Sumber Tentang Metode-Metode Baru (Jakarta : Universitas Indoensia Press - UIP, 1992), 16-18.

${ }^{16}$ Terdapat tiga hal penting yang menjadi karakteristik suatu sistem. Pertama, setiap sistem pasti memiliki tujuan. Tujuan merupakan ciri utama suatu sistem. Tidak ada sistem tanpa tujuan. Tujuan merupakan arah yang harus dicapai oleh suatu perherakan sistem. Kedua, sistem sealu mengandung suatu proses. Proses adalah rangkaian kegiatan. Kegiatan diarahkan untuk mencapai tujuan. Semakin kompeks tujuan maka semakin rumit juga proses kegiatan. Ketiga, proses kegiatan dalam suatu sistem sealu melibatkan dan memanfaatkan berbagai komponen atau unsur-unsur tertentu. Oleh sebab itu, suatu sistem tidak hanya memiliki satu komponen saja. Sistem memerukan dukungan berbagai komponen yang satu sama lain berkaitan. Baca
}

Dirasah, Vol. 2, No. 1, Februari 2019 
Majelis ilmi Padhang Mbulan mempunyai sistem pembelajaran tersendiri dalam menjalankan acara maiyahan-nya. Perbedaan yang sangat mencolok dengan Majelis Taklim pada umunya adalah terkait pemilihan tanggal pelaksanaan dan alokasi acara. Kegiatan Maiyah Padhang Mbulan dilakukan setiap tanggal 15 dalam penanggalan Jawa, yang dimulai sekitar pukul 20.00 WIB sampai pukul 03.00 dini hari. ${ }^{17}$ Dengan alokasi yang sedemikian lama, tentu maiyah Padhang Mbulan mempunyai tujuan pembelajaran yang ingin dicapai.

Adapun tujuan hakiki atau yang sejati dari maiyahan Padhang Mbulan adalah memperdalam ketauhidan dan semakin mendekatkan diri dengan Allah SWT. dengan maiyahan sebagai sarananya. Dengan berkumpul bersama-sama dengan latar belakang yang berbeda-beda dalam bingkai maiyahan, saling member informasi terkait hal apapun berkaitan dengan ilmu dan mempererat jalinan persaudaraan baik dengan sesame muslim dan menghormati non muslim dalam forum maiyah merupakan sebuah tujuan yang agung, yakni mendekatkan diri dengan Allah tanpa sekat apapun merupakan inti spiritualitas Islam.

Hal tersebut setidaknya sangat selaras dengan tujuan dari majelismajelis taklim lain yang mempunyai perbedaan dari segi pelaksanaan kegiatan. Majelis ilmi maiyah setidaknya juga merupakan majelis taklim sebagaimana karakteristiknya, yaitu:

a. Majelis Taklim adalah lembaga pendidikan nonformal Islam.

b. Waktu belajarnya berkala tapi teratur, tidak setiap hari sebagaimana halnya sekolah atau madrasah.

Wina Sanjaya, Strategi Pembeajaran Berorientasi Standar Proses Pendidikan (Jakarta: Kencana, 2007), 49-50.

${ }^{17}$ Menurut Prayogi, Maiyahan dimulai pukul 20.00 hingga 03.00 dini hari. Artinya para jama'ah hadir sebelum pukul 20.00. Suplemen apa yang ampuh untuk mengikat orang duduk selama itu tanpa fasilitas yang memadai? Duduk di terpal atau maksima tikar, tidak ada makanan atau minuman yang disuguhkan. Kalau hujan turun, mereka akan kehujanan. Banyak yang bertanya daya tahan apa sebenarnya yang demikian itu? Harus ada intervensi energi yang memiliki kekuatan untuk melipat waktu dan menggembirakan hati secara luar biasa. Yang menurut Anand Krisna menyebutnya ada cahaya kharisma yang menarik orang-orang untuk bertahan. Lihat Prayogi R. Saputra, Spiritual Jourey; Pemikiran \& Permenungan Emha Ainun Nadjib (Jakarta: Kompas, 2012), 79.

Dirasah, Vol. 2, No. 1, Februari 2019 
c. Pengikut atau pesertanya disebut jama'ah (orang banyak), bukan pelajar atau santri. Hal ini didasarkan kepada kehadiran di Majelis Taklim bukan merupakan kewajiban murid menghadiri sekolah atau madrasah.

d. Tidak ada aturan kelembagaan yang ketat sehingga sifatnya suka rela. Tidak ada kurikulum, yang materinya adalah segala aspek ajaran agama.

e. Bertujuan mengkaji, mendalami dan mengamalkan ajaran Islam di samping berusaha menyebarluaskan. Dengan kata lain adalah untuk memasyarakatkan ajaran Islam.

f. Antara ustadz/guru sebagai pemberi materi dengan jamaah sebagai penerima materi berkomunikasi secara langsung. ${ }^{18}$

Keenam karakteristik tersebut merupakan ciri yang membedakan maiyah Padhang Mbulan dengan lembaga formal ataupun informal lain sebagaimana madrasah atau pondok pesantren. Jika ditinjau dari segi historis perjalanan maiyah, tujuan dari lahirnya maiyah juga identik sebagaimana majelis yang sudah ada pada sejak zaman Rasulullah SAW. ${ }^{19}$

Majelis Taklim (dalam konteks pengertian sekarang) dengan berbagai dimensinya yang berbeda-beda telah berkembang sejak zaman Rasulullah. Apa lagi pada periode Madinah yang mana Islam telah menjadi kekuatan nyata dalam masyarakat, sehingga menjadikan penyelenggaraan pengajian tersebut lebih pesat, seiring dengan perkembangan ajaran Islam di kala itu. Seiring dengan perkembangan tersebut, maka muncullah berbagai jenis kelompok pengajian sukarela disebut dengan halaqah yaitu kelompok pengajian di majelis Nabawi atau al-Haram, biasanya ditandai dengan salah satu pilar masjid untuk tempat berkumpulnya peserta kelompok masing-masing dengan seorang sahabat. ${ }^{20}$ Jika perkumpulan pada zaman tersebut ditandai dengan salah satu pilar masjid, di dalam maiyah identik dengan lingkaran maiyah, yaitu jama'ah yang berkumpul membentuk sebuah lingkaran jika dilihat dari atas, menyerupai pelaksanaan thawaf mengelilingi Ka'bah.

${ }^{18}$ Khozin, Jejak-jejak Pendidikan Islam di Indonesia (Bandung: Tp, 1996), 240.

19 Meskipun tidak disebut dengan istilah Majelis Taklim. Pelaksanaannya dikenal dengan pengajian (taklim bahasa Arabnya). Pengajian Nabi Muhammad saw berlangsung di rumah Arqam bin Arqam secara sembunyi-sembunyi. Kemudian pengajian ini berkembang di tempattempat lain dan dilaksanakan secara terbuka. Hal ini dilandasi dengan adanya perintah Allah swt untuk menyiarkan Islam secara terang-terangan. Lihat Hasbullah, Kapita Selekta Pendidikan Islam, (Jakarta: Grafindo Persada, 1996), 96.

${ }^{20}$ M. Arifin, Kapita Selekta Pendidikan; Islam dan Umum, Cet. III (Jakarta: Bumi Aksara, 1995), 118. 
Tujuan maiyah Padhang Mbulan tersebut sebagaimana tujuan yang dijelaskan oleh Imam Ghazali dan Ahmad D. Marimba terkait dengan tujuan dari Pendidikan Islam. Menurut Imam al-Ghazali, tujuan dari pendidikan Agama Islam adalah kesempurnaan manusia yang bertujuan mendekatkan diri, dalam arti kualitatif kepada Allah SWT. Kesempurnaan manusia yang dimaksud adalah kebahagiaan yang di dunia dan akhirat. Untuk menjadikan insan kamil tidaklah tercipta dalam sekejap mata, tetapi mengalami proses yang panjang dan ada prasyarat-prasyarat yang harus dipenuhi. Dengan bahasa yang agak berbeda Ahmad D. Marimba mengemukakan bahwa "tujuan akhir pendidikan Islam adalah terbentuknya kepribadian Muslim". ${ }^{21}$

Selaras dengan tujuan di atas, bahwa tujuan maiyah dapat dirinci dalam beberapa segmentasi, yakni bermaiyah mental (nafsiyah), moral (hulüqiyah), intelektual ('aqliyah) dan spiritual (ruhāniyah).

2. Pendidik

Pendidik menurut Wiji Suwarno adalah "orang yang lebih dewasa baik dari segi jiwa atau keilmuan yang mampu membawa peserta didik ke arah kedewasaan". ${ }^{22}$ Sedangkan yang dimaksud dengan pendidik dalam pembelajaran Majelis Taklim adalah orang yang memiliki kewenangan untuk menyampaikan ilmu yang dimilikinya kepada para jamah dalam pelaksanaan pembelajaran yang ada dalam Majelis Taklim tersebut. Dalam hal ini, pendidik dapat langsung dari pengasuh atau pendiri Majelis Taklim setempat (Kiai) ataupun Ustadz yang langsung ditunjuk oleh seorang Kiai.

Dalam maiyah Padhang Mbulan term pendidik identik dengan sebutan narasumber. Terdapat dua jenis narasumber dalam maiyah yakni narasumber tetap dan tidak tetap. Narasumber tetap dalam Padhang Mbulan antara lain adalah Emha Ainun Nadjib (Cak Nun), Achmad Fuad Efendi (Cak Fuad), Adil Amrullah (Cak Dil) dan Jama'ah maiyah itu sendiri. Sedangkan narasumber tidak tetapnya adalah mereka yang datang dan kemudian mengisi forum ini secara bergantian. Di antaranya adalah Cak Nang atau Anang Ansharullah (Jombang), Islamiyanto (Yogyakarta), Zainul (Vokalis Kyai Kanjeng asli Mojokerto), Toto Rahardjo (Pengisi tetap Mocopat Syafaat), Ian L. Betts (Penulis Buku Jalan Sunyi Emha), Musthofa W. Hasyim (Ketua Nahdlatul Muhammadiyin), Khoirul Huda (perwakilan dari Bang Wetan Surabaya),

${ }^{21}$ Zuhairini dkk, Metodologi Pendidikan Agama, Cet: 1 (Solo: Ramadhani, 1996), 17.

${ }^{22}$ Wiji Suwarno, Dasar-dasar Ilmu Pendidikan (Yogyakarta: Ar-Ruzz, 2006), 37.

Dirasah, Vol. 2, No. 1, Februari 2019 
Rachmad (perwakilan dari Kenduri Cinta Surabaya), Bang Mathar (perwakilan dari Juguran Syafa'at Banyumas), Titut Edi Purwanto, KH. Muzammil (Pesantren Padhang Mbulan Parangtritis Yogyakarta), Kiai Marzuki Kurdi, Pak Tjuk, Sabrang Mowo Damar Panuung ('Noe' vokalis Letto Band atau anak Cak Nun), Kyai Kanjeng dan lain sebagainya. ${ }^{23}$

Berkaitan dengan penyebutan Kyai, guru atau ustadz terhadap diri Cak Nun, ia selalu menolak segala label pada dirinya termasuk guru atau kyai, ia selalu menolak eksistensi dan kemasyhuran pada dirinya. Ia menjelaskan:

.... Guru sejati kita adalah Allah. Dialah yang seratus persen punya saham terhadap kita. Ilmu yang kita punyai juga saham pinjaman dari Allah. Jangan membatasi diri, bahwa mencari ilmu harus di sekolahan, karena betapa dimanapun Allah menebar ilmu dan hikmah. Jangan membatasi guru itu harus di sekolah, karena kita bisa berguru terhadap apapun, siapapun. Bisa berguru kepada air, api, tanah, cacing, anjing, mega, kilat, dan .... tak terbatas. ${ }^{24}$

\section{Subyek didik (jama'ah)}

Subyek didik (jam'ah); Identik dengan sebutan Jama'ah Maiyah yang terdiri dari masyarakat yang berlatar belakang heterogen bersama-sama dalam lingkaran maiyah. Ha ini tentulah selaras dengan teori yang menyatakan bahwa Subjek didik merupakan anggota masyarakat yang berusaha mengembangkan potensi diri melalui proses pembelajaran yang tersedia melalui jalur, jenjang, dan jenis pendidikan tertentu. ${ }^{25}$

Subjek atau peserta didik pengajian Majelis Taklim tidak dibatasi dalam tingkat usia, kemampuan atau lainnya, tapi siapa saja yang berminat boleh mengikutinya. Untuk itu pesertanya sangat heterogen, tidak ada tingkatan tertentu, yang penting mereka ikhlas dan tertib dalam mengikuti pengajian yang dilaksanakan. ${ }^{26}$

\section{Materi Pembelajaran}

Materi atau tema-tema dalam maiyah Padhang Mbulan terdiri dari tematema actual dan kekinian tanpa mengesampingkan tema keagamaan yang

${ }^{23}$ Observasi, Majelis Ilmi Maiyah Padhang Mbulan, Juni-Oktober 2013.

${ }^{24}$ Cak Nun, Majelis Ilmi Padhang Mbulan, Oktober 2013.

${ }^{25}$ Wiji Suwarno, Dasar-dasar Ilmu Pendidikan (Yogyakarta: Ar-Ruzz, 2006), 36.

${ }^{26}$ Puslitbang Kehidupan Keagamaan, Peningkatan Peran Serta Masyarakat dalam Pendalaman Ajaran Agama Melalui Majelis Taklim (Jakarta: Badan Litbang dan Diklat Departemen Agama RI, 2007), 21. 
berbasis al-Qur`an dan akhlaq sufistik. Hal tersebut diperuntukkan untuk menjawab problematika masyarakat dan disesuaikan dengan kebutuhan masyarakat setempat yang tidak sempat mengenyam pendidikan formal seperti; pengetahuan agama sebagai materi pokok meliputi, materi fiqh, hadith, tauhid dan tafsir dan lain sebagainya serta pengetahuan-pengetahuan umum yang faktual dan kontekstual.

Dalam struktur acara rutin majelis ilmu Padhang mbulam Jombang, Bangbang Wetan Surabaya, Obor Ilahi Malang, Kenduri Cinta Jakarta, Mocopat Syafaat Yogyakarta, dan Gambang Syafaat Semarang adalah sebagai berikut:

a. Acara dimulai dengan Tadarrus AlQuran. (Mulai Padhangmbulan 30 Januari 2010 tadarus dimulai dari awal yaitu juz 1 oleh JM PMb, sampai juz berapa PMb berheti kemudian akan disambung JM BBW pada acara BBW, kemudian disambung JM Obor Ilahi pada acara Obor Ilahi, disambung lagi JM KC pada acara Kenduri Cinta, diteruskan lagi oleh JM Mocopat Syafaat pada acara Mocopat Syafaat, dan disambung JM Gambang Syafaat pada acara Gambang Syafaar, dan balik lagi ke Padhangmbulan, dan seterusnya).

b. Wirid dan shalawat Maiyah. Yang disepakati dalam pertemuan ini adalah aransemen baru Kiai Kanjeng: Hasbunallah, Robbi ya Robbi, Subhanallah, dan Liannahum.

c. Pendalaman buku Tafsir Cak Fuad "Maiyah di dalam AlQuran". Mulai Padhangmbulan 30 Januari 2010 dan berujung pada Gambang Syafaat, teman-teman JM [Jamaah Maiyah] akan mendalami topik Pola Hubungan Maiyah sub topik a. Maiyah Allah Swt dengan Para Hamba. Sesudah Gambang Syafaat mendapat giliran, maka setelah itu Padhangmbulan akan memasuki sub topik baru. Metode tafsirnya, salah satunya, adalah sebagaimana diterangkan Mas Toto Rahardjo (baca Daur Tafsir Kontekstual). Prinsipnya, tafsir mengedepankan keterkaitan langsung dan konkret antara ayat dan pengalaman hidup Jama'ah Maiyah. Ada proses afirmasi dan konfirmasi atau sebaliknya.

d. Dialog dll. Menu 1,2, dan 3 bisa disebut menu wajib. Sedang pada urutan yang keempat ini bisa muncul dialog- 
dialog, penampilan-penampilan, dan kemungkinankemungkinan lain. ${ }^{27}$

Dapat dipahami bahwa dalam Majelis Ilmi Padhang Mbulan tidak terdapat tema atau materi yang pasti, namun segala informasi yang disampaikan oleh narasumber selalu dipagari dengan tafsir kontekstual dan akhlaq sufistik yang dikemas dengan penyampaian pemahaman menggunakan bahasa budaya masyarakat sehingga mudah dipahami dan disertai dengan guyonan.

5. Metode Pembelajaran

Metode merupakan salah satu sarana dalam pencapaian tujuan. Demikian halnya dalam pembelajaran Agama di lingkungan Majelis Taklim. Dalam menghadapi peserta didik (masyarakat) yang heterogen baik dari usia, kemampuan, daya tangkap dan jumlah yang tidak menentu, para ustadz atau penceramah sangat sulit dalam menentukan metode yang paling tepat diterapkan. Dalam QS. al-Maidah ayat 35 dijelaskan;

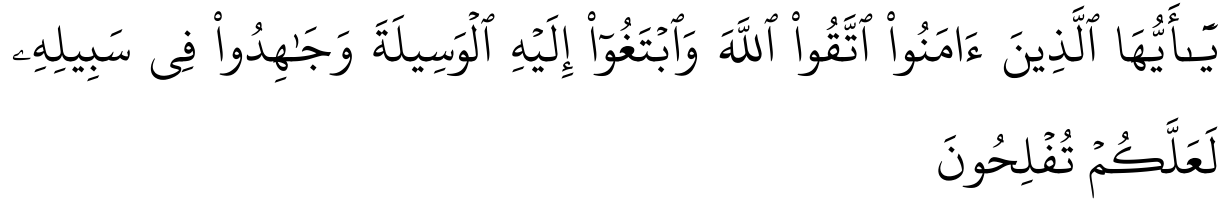

Artinya: "Hai orang-orang yang beriman, bertakwalah kepada Allah dan carilah jalan yang mendekatkan diri kepada-Nya, dan berjihadlah pada jalan-Nya, supaya kamu mendapat keberuntungan". (QS. AlMaidah: 35$){ }^{28}$

Implikasi ayat tersebut dalam pembelajaran adalah bahwa dalam proses pelaksanaan pembelajaran dibutuhkan adanya metode yang tepat guna menghantarkan tercapainya tujuan dalam pembelajaran tersebut. Guru yang kreatif adalah mereka yang selalu berpikir dan membuat yang berbeda dari hari-ke hari. Ia selalu berproses (becoming atau menjadi) untuk sampai pada kesempurnaan. Dari sini jelaslah bahwa metodologi pembelajaran sangat berfungsi strategis dalam menyampaikan materi, bahkan ada sebuah adagium yang menyatakan bahwa "metode lebih utama dari pada materi", disebabkan

\footnotetext{
${ }^{27}$ Struktur tersebut merupakan kesepakatan yang dicapai oleh perwakilan Jamaah Maiyah pada Pertemuan Pematangan Hasil Kesepakatan Haflah Maiyah 2009 dan Pematangan Panduan Acara Rutin Majlis Ilmu Maiyah pada 28 Januari 2010 di Kadipiro, Yogyakarta. Redaksi Progress, "Struktur Acara Majlis Ilmu Maiyah" dalam http://www.maiyah.net/2012/04/struktur-acara-majlis-ilmu-maiyah.html, diakses 05 Juni 2013. ${ }^{28}$ QS. Al-Maidah [05]; 35.
} 
materi itu bagaikan raga yang harus digerakkan oleh jiwa. Tanpa adanya penggerak yang membawa pada tujuan maka proses pendidikan tidak akan tercapai secara maksimal. ${ }^{29}$

Dalam maiyah Padhang Mbulan metode pembelajaran yang digunakan antara lain adalah ceramah interaktif dan komunikatif disertai canda atau humor, metode dekonstruksi-rekonstruksi pemahaman atas nilai-nilai, tanya jawab dan diskusi, panggung bebas dan terbuka, analogi dengan bahasa budaya, demonstrasi dan metode musikal adalah metode maiyah Padhang Mbulan.

Bisa dikatakan bahwa metode maiyah tersebut merupakan perpaduan antara pendidikan dan hiburan atau yang dikenal dalam dunia pendidikan dengan sebutan edutainment. Kata edutainment terdiri atas dua kata, yaitu Education yang berarti pendidikan dan kata entertainment artinya hiburan. Dengan demikian, ada upaya untuk menciptakan suasana dan proses pembelajaran yang menyenangkan dalam dunia pendidikan dengan memadukan antara dua aktivitas, yaitu pendidikan dan hiburan. Jadi, edutainment bisa di definisikan sebagai proses pembelajaran yang didesain dengan memadukan antara muatan pendidikan dan hiburan secara

${ }^{29}$ Ada adagium lain yang menyatakan bahwa metode itu lebih utama atau lebih penting dari pada materi atau kurikulum yakni_"at-Thariqah Ahammu Mina-l-Maddah". Adapun al-Qur'an sendiri secara eksplisit tidak menjelaskan arti dari metode pendidikan. Namun kata metode dalam bahasa Arab dibahasakan dengan kata at-Thariqah, banyak dijumpai dalam al-Qur`an. Menurut Muhammad Abd al-Baqi, didalam al-Qur`an kata at-Thariqah di ulang sebanyak sembilan kali. Salah satunya kata ini terkadang dihubungkan dengan sifat dari jalan tersebut, seperti at-Thariqah al-mustaqimah, yang diartikan jalan yang lurus. Hal ini terdapat dalam alQur`an surat al-Ahq回f ayat 30, yang terjemahannya: Mereka berkata: "Hai kaum kami, Sesungguhnya kami telah mendengarkan Kitab (al-Qur`an) yang telah diturunkan sesudah Musa yang membenarkan kitab-kitab yang sebelumnya lagi memimpin kepada kebenaran dan kepada jalan yang lurus". Dari ayat tersebut dapat dijelaskan bahwa metode atau jalan oleh alQur'an dilihat dari sudut objeknya, fungsinya, akibatnya, dan sebagainya. Ini dapat diartikan bahwa perhatian al-Qur`an terhadap metode demikian tinggi, dengan demikian al-Qur`an lebih menunjukkan isyarat-isyarat yang memungkinkan metode ini berkembang lebih lanjut. Dengan berlandaskan pada beberapa definitif tersebut, Menurut Zakiyah Darajat, ditegaskan bahwa metode pendidikan merupakan sebuah mediator yang mengolah dan mengembangkan suatu gagasan sehingga menghasilkan suatu teori atau temuan untuk menyampaikan sebuah visi pendidikan kepada tujuannya. Lihat Zakiyah Darajat, Dkk. Metodologi Pengajaran Agama Islam (Bumi Aksara, Jakarta, 1996), 35-36.

Dirasah, Vol. 2, No. 1, Februari 2019 
harmonis sehingga aktivitas pembelajaran yang berlangsung menyenangkan. ${ }^{30}$

\section{Media Pembelajaran}

Adapun media pembelajaran yang dominan dalam Maiyah Padhang Mbulan adalah manusia itu sendiri dibantu dengan media sekunder lain seperti pemanfaatan berbagai alat musik baik tradisional dan modern.

Dengan mengenal media pembelajaran dan memahami cara-cara penggunaannya akan sangat membantu tugas pendidik dalam meningkatkan efektifitas proses pembelajaran. Sehingga pendidik dituntut untuk mampu memanfaatkan media pembelajaran agar supaya proses pembelajaran tidak mengalami kesulitan dalam mencapai tujuan pembelajaran. Bahkan tidak mustahil dapat mengakibatkan kegagalan mencapai tujuan tersebut, bila tidak dikuasai sungguh-sungguh oleh pendidik. ${ }^{31}$

7. Evaluasi hasil pembelajaran

Evaluasi pembelajaran merupakan cara atau teknik penilaian terhadap tingkah laku manusia (anak didik) berdasarkan standar perhitungan yang bersifat komprehensif dari seluruh aspek-aspek kehidupan mental-psikologis dan spiritual-religius, karena manusia bukan saja sosok pribadi yang tidak hanya bersikap religius, melainkan juga berilmu dan berketerampilan yang sanggup beramal dan berbakti kepada Tuhan dan masyarakat. ${ }^{32}$ Jadi evaluasi merupakan proses penilaian untuk menggambarkan prestasi yang dicapai oleh peserta didik sesuai dengan kriteria yang telah ditetapkan.

Adapun maksud dan tujuan dari evaluasi adalah, menentukan hasil yang dicapai oleh peserta didik. Bagaimanapun, penetapan proses pembelajaran secara keseluruhan. Termasuk tujuan yang akan dicapai oleh peserta didik, media pembelajaran, teknik pendekatan dalam pembelajaran, bahkan sifat efektif seorang pendidik memerlukan evaluasi. Dimana evaluasi dilakukan sebelum, selama dan sesudah suatu proses pembelajaran. ${ }^{33}$

${ }^{30}$ Hamruni, Edutainment dalam Pendidikan Islam dan Teori-teori Pembelajaran Quantum (Yogyakarta: Fakultas Tarbiyah UIN Sunan Kalijaga, 2009), 50. Iihat juga Moh. Sholeh Hamid, Metode Edutaunment (Yogyakarta: Diva Press, 2012), 17.

31 Syaifullah Sagala, Konsep dan Makna Pembelajaran (Untuk Membantu Memecahkan Problematika Belajar dan Mengajar) (Bandung: Alfabeta, 2007), 163-164.

${ }^{32}$ H.M Arifin, Ilmu Pendidikan Islam (Tinjauan Teoritis dan Praktis Berdasarkan Pendekatan Interdisipliner) (Jakarta: Bumi Aksara, 2003), 162.

${ }^{33}$ Syaifullah Sagala, Konsep dan Makna Pembelajaran, 164. 
Evaluasi hasil pembelajaran maiyah Padhang Mbulan dalam hal ini bersifat reflektif berupa perenungan-perenungan, sumbang saran dan dialogisasi serta Tanya jawab. Dalam segmen pembelajaran, evaluasi disesuaikan dengan metode yang diterapkan dan hal tersebut merupakan bagian dari alat ukur yang digunakan untuk menentukan taraf keberhasilan sebuah proses belajar mengajar atau untuk menentukan taraf keberhasilan sebuah program pembelajaran atau penyajian materi.

\section{Learning society dalam majelis taklim padhang mbulan}

Learning society dalam majelis ilmi maiyah Padhang Mbulan merupakan wahana pembelajaran bagi masyarakat yang berlatar belakang heterogen tanpa dibatasi usia, waktu dan gender. Learning society dalam majelis ilmi maiyah Padhang Mbulan dapat digolongkan menjadi tiga fase berkaitan yaitu input, proses dan output. Input berupa kesadaran masyarakat (jama'ah maiyah) dalam belajar dan mencari pengetahuan, proses berupa intensitas keikutsertaan dalam kehadiran pada forum maiyah dan output berbentuk karya atau program yang dihasilkan jama'ah maiyah.

Dengan adanya sistem pembelajaran maiyah Padhang Mbulan mampu menggugah kesadaran masyarakat dalam belajar dan memperoleh pengetahuan dengan mengikuti maiyah Padhang Mabuan. Karena dalam pengajian Padhang Mbulan tersebut berlangsung dialogisasi bermacam-macam segmen dan terbuka untuk siapa saja tentang berbagai persoalan masyarakat untuk segala upaya kebaikan dan kebenaran manusia, ia bermuatan spiritual, dialektika ilmu sosial, ilmu hidup, informasi, pendidikan, politik kenegaraan, ekonomi perdagangan, hingga harga hasil pangan dan lain sebagainya.

Sehingga Padhang Mbulan dengan jamaah maiyahnya bukan saja sekedar peristiwa pengajian tetapi sudah menjadi nilai di dalam masyarakat. Majelis Ilmi Maiyah Padhang Mbulan juga mampu melahirkan karya dan kreasi, seperti Buletin Maiyah Jawa Timur yang terbit setiap acara maiyahan Padhang Mbulan digelar, radio live streaming via internet yang dapat diakses oleh jama'ah yang berada di luar daerah dan juga yang cukup menggembirakan adalah lahirnya Pesantren Padhang Mbulan yang sudah resmi berjalan sejak hari Sabtu, 12 Oktober 2013. Setiap ba'da Ashar, anak-anak SMA Global ngaji hadith. Lalu ba'da Isya' mereka belajar lagi dengan materi yang bervariasi. Sejauh ini sudah pernah diberikan pelajaran Bahasa Arab percakapan dan dasar-dasar 
kepemimpinan. Kemudian $b a^{\prime} d a$ Shubuh difokuskan pada tadarus dan tadabur Al-Qur'an. Sementara itu, selang waktu antara Maghrib sampai Isya' diisi dengan kajian umum untuk masyarakat sekitar. Sudah banyak ibu-ibu dan bapakbapak yang mengikutinya. ${ }^{34}$

Paparan diatas secara jelas sesuai dengan apa yang dijelaskan oleh Ahmad Sudrajat, bahwa pembentukan society learning harus melalui setiap individu masyarakat. Jika setiap individu sudah muncul kemauan dan kesadaran untuk belajar, maka di situlah akan muncul suatu budaya masyarakat belajar (society learning). ${ }^{35}$

Majelis Ilmi Padhang Mbulan sebagai wahana atau sarana dalam mewujudkan learning society atau masyarakat belajar setidaknya sudah dilaksanakan meski masih secara tersirat semenjak berdirinya majelis PB ini. Beberapa contoh learning society dan karya-karya yang lahir dari majelis ilmi ini antara lain adalah:

1. Maiyah sebagai gerakan menulis

Gerakan maiyah ini sudah berjalan cukup lama. Di bawah naungan Padhang Mbulan saja sudah berjalan kurang lebih 15 tahun. Dalam kurun dekade ini banyak hal yang terjadi berkaitan dengan kejadian nyata, perilaku magic, serta ketajaman intelektual yang tiba-tiba mencuat. Bahkan kejadian tersebut kadar kualitasnya layak untuk dijadikan rumus-rumus baru dalam kehidupan. Ada juga segmen pola pikir yang dapat dijadikan dasar hukum, baik sar'i dan haqiqati. Alangkah mubadzirnya jika semua ini tidak terdokumentasikan dengan detail. Memang ada beberapa anggota yang merekam kegiatan jama'ah ini. Tetapi acapkali jadi pertanyaan baru yang tumpang tindih berganti. Seberapa efektifkah kegiatan pendokumentasian dari beberapa anggota baik CD, shooting atau yang lainnya bagi jama'ah? Apalagi untuk disebarkan ke masyarakat luas yang belum mengetahui kegiatan ini.

Kita perlu berfikir ulang dari semua pihak yang terlibat, khususnya para jama'ahnya. Seri berikutnya yang terpenting setelah manajemen pelaksanaan adalah terbentuknya manajemen pendokumentasian. Agar kesan yang ditimbulkan oleh gerakan besar maiyah bukanlah hanya sekedar aktifitas yang nguyahi segoro. Yakni sebuah acara berproses pada datang, mendengarkan, dan akhirnya bubar. Padahal di sisi lain, kadar pemikiran Cak Nun terkadang

${ }^{34}$ Observasi, Majelis Ilmi Maiyah, Juni-Oktober 2013.

${ }^{35}$ Akhmad Sudrajat, "Masyarakat Beajar" dalam http://akhmadsudrajat.wordpress.com, diakses 18 Oktober 2013.

Dirasah, Vol. 2, No. 1, Februari 2019 
tidak termuat dalam ruang otak pendengarnya. Alangkah tepatnya jika setiap moment acara ini berlangsung, ada beberapa orang yang merangkum, mengedit, dan kemudian mencetak dalam bentuk tulisan. Yang pada saat senggang dapat dijadikan bahan kajian ulang oleh anggota jama'ah.

2. Membentuk literasi maiyah

Hasil pendokumentasian tulisan tersebut kemudian dicarikan formula alternatif yang sewaktu-waktu dapat dijadikan acuan jama'ah yang lain untuk bahan telaah. Minimal dibentuk mini mading. Supaya terjangkau bagi jama'ah maiyah yang belum mampu bergerak di dunia internet. Dalam skala besar dibentuk sampai ke tingkat Bloger atau Google.

Literasi maiyah ini bisa bersifat out contribution (kontribusi keluar) dan in contribution. Kontribusi keluar adalah literatur yang diserap dan di lahirkan maiyah di taruh sejajar dalam literatur luar semisal, toko buku, perpustakaan dan lain-lain untuk menambah khasanah perbukuan dunia pendidikan. Sedangkan yang dimaskud literasi dalam adalah pemasokan buku-buku karya tulis dari luar maiyah ditaruh sejajar dengan buku khusus maiyah. Buku yang di pasok dari luar berfungsi menambah wawasan yang berhubungan dengan maiyah, dan atau juga bisa sekedar menghantarkan pemahaman ke literatur buku yang dirumuskan maiyah. Dalam hal ini minimal semua anggota jama'ah maiyah berkomitmen membikin semacam laboratorium pustaka. Lantas bagaimanakah target pembentukan laboraturium ini bisa tercapai? Solusi yang paling mudah adalah bila setiap jama'ah yang mempunyai buku, merelakan menanam saham bukunya untuk meletakkan di perpustakaan maiyah.

3. Mewujudkan jama'ah yang progresif

Dari seluruh uraian di atas dapat kita tarik sebuah pemetaan yang meliputi identifikasi setiap jama'ah yang di tarik berdasarkan garis lajur kadar pendidikan dan kreatifitas personalnya. Maka kita temukan minimal 2 hal. Pertama: ada jama'ah maiyah yang hanya mampu datang dan mendengarkan, kedua: ada juga jama'ah yang mampu berkreatifitas membukukannya dalam tulisan. Pembauran kedua corak jama'ah ini berlangsung terus menerus dalam setiap pertemuan. Peristiwa adhesiv inilah yang akan mewujudkan kekuatan corak dan warna baru dalam literatur maiyah. Dimana jama'ah yang tidak mampu menulis bersedia menceritakan pengalaman hidupnya kepada jama 'ah yang mampu menulis. Sebab dimungkinkan pengalaman jama'ah yang tidak

Dirasah, Vol. 2, No. 1, Februari 2019 
bisa menulis mempunyai wawasan ilmu dahsyat dibanding yang mampu menulis. Proses inilah yang akan melahirkan bentuk hegemoni baru dalam sejarah penulisan. Dimana sebuah karya diangkat dengan bahan dasar riset yang detail dari pori-pori file otak masyarakat. Lebih objektif empiris dari pada buku yang dilahirkan atas penulis individu.

Jama'ah maiyah ini adalah gerakan besar, tentu idealnya para penulis jama 'ahnya harus menghasilkan karya yang berbobot, dan tidak sekedar buku pinggiran jalan. Untuk mewujudkan jama'ah maiyah yang progresif bukanlah hal yang sulit. Asalkan antar anggota jama'ahnya bersama-sama bergandengan tangan untuk satu tekad, yakni meninggalkan suatu tanda bahwa pernah adanya tampilan sejarah pada anak cucu negara ini kelak.

Para penulis jama'ah inilah yang kita ibaratkan ujung mata tombak. Mereka adalah personal yang bersifat lancip dan mengerucut yang kemudian berakhir di ujung. Mengapa demikian? Karena kreatifitas dan kecermatan merekalah yang mempunyai nilai lebih dalam sebuah gerakan. Tentu para penulis inilah yang akan mampu menjelaskan duduk persoalan secara jelas tentang apa dan bagaimana maiyah bergerak kedelapan penjuru mata angin di berbagai lini sektor kehidupan. ${ }^{36}$

Berdasarkan berbagai pendapat yang dikemukakan, secara rinci memang belum disebutkan oleh para ahli yang memiliki gagasan tentang konsep learning society ini. Akan tetapi, berdasar dari wacana dalam gagasan para ahli psikologi di atas tentang konsep ini, dapat ditarik kesimpulan dari karakteristik masyarakat belajar di atas. Karakteristik tersebut adalah sebagai berikut:

a. Hasil belajar diperoleh dari kerja sama dengan orang lain.

b. Belajar tidak harus di kelas atau sekolah. Tapi bisa memanfaatkan masyarakat dan hasil budaya masyarakat yaitu lingkungan sekitar.

c. Belajar tidak harus melalui guru, tetapi setiap orang bisa menjadi sumber belajar. Bahkan tukang becak bisa menjadi pengajar untuk menjelaskan tentang tata tertib lalu lintas.

d. Belajar tidak harus menggunakan media belajar seperti yang ada di sekolah, dan setiap hal bisa menjadi media belajar, termasuk memanfaatkan lingkungan sebagai media belajar. Contohnya adalah kantor kepala desa sebagai sarana belajar tentang perangkat desa.

${ }^{36}$ Sabrank Suparno, "Ujung Tombak Maiyah" daam http://www.maiyah.net, diakses 06 Juni 2013. 
e. Belajar berlangsung tanpa mengenal usia dan bahkan terjadi seumur hidup.

Berdasarkan pada karakteristik konsep learning society di atas, karakteristik tersebut dapat dirumuskan sebagai berikut:

a. Everyone is teacher. Pengetahuan, keterampilan, dan sebagainya yang dapat meningkatkan pengetahuan dan keterampilan diperoleh dari siapa saja.

b. Everywhere is school. Artinya dimana saja bisa terjadi proses belajar.

c. Everything is usefull. Artinya masyarakat adalah sumber belajar. Sehingga apa saja yang terdapat masyarakat dapat dipelajari untuk menjadi sesuatu yang berguna. Sehingga segala hal yang memiliki kontribusi positif dapat dipelajari.

d. Everytime is studying. Yaitu pendidikan berlangsung seumur hidup (long life education). Pendidikan berlangsung tidak hanya pada usia anak-anak, tetapi berlangsung sepanjang hayat.

Seperti yang dikutip oleh Muljono dari al-Rasyidin dan Samsul Nizar mengungkapkan beberapa harapan yang ingin dicapai melalui learning society, khususnya jika dikaitkan dengan perwujudan masyarakat madani, menurut Tim Nasional Reformasi Menuju Masyarakat Madani adalah sebagai berikut:

a. Terciptanya masyarakat yang beriman dan bertakwa kepada Tuhan Yang Maha Esa;

b. Terciptanya masyarakat yang demokratis dan beradab yang menghargai adanya perbedaan pendapat;

c. Masyarakat yang mengakui hak-hak asasi manusia;

d. Masyarakat yang tertib dan sadar hukum, budaya malu apabila melanggar hukum yang melekat dalam semua lapisan kehidupan kenegaraan dan kemasyarakatan;

e. Masyarakat yang percaya pada diri sendiri, memiliki kemandirian dan kreatif terhadap pemecahan masalah yng dihadapi, masyarakat memiliki orientasi yang kuat pada penguasaan ilmu dan teknologi;

f. Sebagai bagian dari masyarakat global, yang memiliki semangat kompetitif dalam suasana kooperatif, penuh persaudaraan dengan bangsa-bangsa lain dengan semangat kemanusiaan yang universal;

g. Terwujudnya tatanan masyarakat yang beradab yang menjunjung tinggi nilai-nilai luhur dan martabat manusia; 
h. Mewujudkan masyarakat belajar yang tumbuh dari masyarakat, oleh masyarakat dan untuk masyarakat. ${ }^{37}$

Berdasarkan uraian tentang perwujudan dan karakteristik dari learning society tersebut, maka majelis ilmi Padhang Mbulan merupakan wahana dan gerakan yang mampu mengakomodir masyarakat untuk memiliki kesadaran dalam belajar. Hal tersebut terangkum dalam Ikrar Maiyah dan Negeri Maiyah di bawah ini sebagai pungkasan pembahasan pada bagian ini.

1. Ikrar Maiyah

a. Agar supaya kita saling menjamin, bahwa di dalam lingkaran kita tidak ada kotoran -kotoran batin, kepalsuan niat, kecurangan pikiran, atau apapun yang membuat Muhammad menitikkan air mata dan membuat Allah mengurangi atau bahkan membatalkan kasih sayangnya kepada kita.

b. Agar supaya perjalanan hijrah demi hijrah kita tidak disesatkan oleh arus masyarakat, oleh Allah atau oleh diri kita sendiri.

c. Agar supaya perjalanan jihad kita tidak disertai oleh dendam dan ketakaburan.

d. Agar supaya perjalanan ijtihad kita tidak didzalimi oleh mahluk apapun, serta tidak melalimi diri sendiri.

e. Agar perjalanan mujahadah kita dianugerahi bekal iman dan istiqāmah, bekal kekuatan dan muțainnah, bekal penghidupan yang barākah, pintu rezeki yang membuka lebar-lebar atas perjuangan kita, pintu kegembiraan, keasyikan uluhiyah, serta perlindungan dari Quwwatihī wa haulih.

Maka:

a. Kami berkumpul melingkar menghadap-Mu dan memunggungi dunia

b. Kami berkumpul melingkar menumpahkan cinta kepada-Mu, karena telah dilukai hati kami oleh cinta dunia, negara serta golongan-golongan manusia.

c. Kami berkumpul melingkar menyanyikan lagu-lagu untuk kekasih-Mu karena ummat manusia lebih menyukai kepalsuan.

d. Kami berkumpul menciptakan lingkaran kebersamaan antara harnba-hamba yang dilemahkan oleh pelaku-pelaku kekuasaan dan keuangan.

37 Pudji Muljono, Learning Society, Penyuluhan Dan Pembangunan Bangsa, Jurnal Penyuluhan, Vol. 3, No. 1, Maret 2007, 3. 
e. Kami berkumpul merapatkan lingkaran kebersamaan antara hamba-hamba yang dilalimi oleh kebohongan dan kemunafikan kaum mutakabbirun.

f. Kami berkumpul memadatkan kesatuan antara hamba-hamba yang diremehkan dan kini mengerti bahwa diremehkan. Antara hamba-hamba yang ditindas dan kini mengerti bahwa ditindas, antan hamba-hamba yang direndahkan dan kini mengerti bahwa direndahkan, antara hamba-hamba yang dibuang dan kini mengerti bahwa dibuang.

g. Kami berkumpul menghidupi lingkaran kesadaran, kepahaman dan kemengertian akan dusta dan kebohongan dunia.

h. Kami berkumpul membangkitkan pengetahuan dan ilmu bahwa kami dibodohkan, difitnah, dimusnahkan, dan dibunuh sebelum kematian.

i. Kami berkumpul menebar jaring lingkman para pecinta-Mu, para pecinta kekasih-Mu, para pecinta kesejatian, para pecinta kebenaran yang sungguh-sungguh kebenaran, para pecinta cinta yang benar-benar cinta.

j. Kami berkumpul melingkar bersholawat bersama-Mu serta bersama para malaikat-Mu untuk manusia agung pilihan-Mu, Muhammad SAW.

k. Kami berkumpul merangkai lingkaran ma'iyyatul hubbi, ma'iyyatul ḥaqqi, fì ma'iyyatillīhi jalla jalālah.

\section{Negeri Maiyah}

Kebersamaan dengan Allah dan Rasullullah berarti (berdasarkan pembidangan):

Bermaiyah:
a. Kepada Allah
b. Kepada Rasullullah
c. Kepada Aulia \& Ulama
d. Kepada diri sendiri
e. Kepada sesama Jamaah Maiyah
f. Kepada sesama Kaum Muslimin
g. Kepada sesama saudara sebangsa
h. Kepada sesama ummat manusia
i. Kepada negara dan pejabat
j. Kepada alam/bumi/tanah air

Bermaiyah:

a. Mental (nafsiyah)

Dirasah, Vol. 2, No. 1, Februari 2019 

b. Moral (hulüqiyah)
c. Intelektual ('aqliyah)
d. Spiritual (ruhāaniyah)

Bermaiyah:

a. Bidang kemanusiaan

b. Bidang sosial budaya

c. Bidang ekonomi

d. Bidang politik dan negara ${ }^{38}$

\section{Penutup}

Berdasarkan paparan data dan pembahasan hasil temuan penelitian, dapat diketahui bahwa majelis ilmi Maiyah Padhang Mbulan memiliki sistem pembelajaran sendiri dengan ala maiyahnya, yang meliputi; (a) Tujuan pembelajaran; Tujuan dari maiyah Padhang Mbulan adalah memperdalam ketauhidan dan semakin mendekatkan diri dengan Allah SWT. dengan maiyahan sebagai sarananya. Maiyah sebagai sumber informasi pengetahuan ('ilm) terhadap siapa saja, termasuk non muslim. (b) Pendidik (narasumber); Pendidik terdiri dari narasumber tetap dan tidak tetap. Narasumber tetap sekaligus pengasuh maiyah Padhang Mbulan adalah Cak Nun, Cak Fuad dan jama'ah maiyah itu sendiri. Sedang narasumber tidak tetap adalah para tamu undangan majelis maiyah Padhang ini. (c) Subyek didik (Jam'ah); Identik dengan sebutan Jama'ah Maiyah yang terdiri dari masyarakat yang berlatar belakang heterogen bersama-sama dalam lingkaran maiyah. (d) Materi; Materi dalam maiyah Padhang Mbulan terdiri dari tema-tema aktual dan kekinian, seperti penentuan awal puasa dan awal 'id al-Fitri, demokrasi, pluralisme tanpa mengesampingkan tema keagamaan yang berbasis al-Qur`an dan akhlaq sufistik. (e) Metode Pembelajaran; Ceramah interaktif dan komunikatif disertai canda atau humor, metode dekonstruksi-rekonstruksi pemahaman atas nilai-nilai, tanya jawab dan diskusi, panggung bebas dan terbuka, analogi dengan bahasa budaya, demonstrasi dan metode musikal adalah metode maiyah Padhang Mbulan. (f) Media Pembelajaran; Media yang dominan dalam Maiyah Padhang Mbulan adalah manusia itu sendiri dibantu dengan media sekunder lain seperti pemanfaatan berbagai alat musik baik tradisional dan modern. (g) Evaluasi hasil pembelajaran; Evaluasi bersifat reflektif berupa perenungan-perenungan, sumbang saran dan dialogisasi serta tanya jawab.

${ }^{38}$ Dokumen Padhang Mbulan. 
Adapun learning society dalam majelis ilmi maiyah Padhang Mbulan merupakan wahana pembelajaran bagi masyarakat yang berlatar belakang heterogen tanpa dibatasi usia, waktu, kapasitas keilmuan, profesi dan gender. Learning society dalam majelis ilmi maiyah Padhang Mbulan dapat digolongkan menjadi tiga fase berkaitan yaitu input, proses dan output. Input berupa kesadaran masyarakat (jama'ah maiyah) dalam belajar dan mencari pengetahuan. Proses berupa intensitas keikutsertaan dalam kehadiran pada forum maiyah. Output berbentuk karya atau program yang dihasilkan jama'ah maiyah.

Implikasi teoritis dari penelitian tentang Sistem Pembelajaran Maiyah Padhang Mbulan dalam Mewujudkan Learning Society di Jombang Jawa Timur tersebut bagi kalangan akademisi khususnya Prodi PAI adalah dengan membangun kesadaran berpikir benar dan kebersamaan dalam membentuk masyarakat pembelajar di mana pun, kapan pun dan kepada siapa pun. Artinya adalah bahwa belajar tidak hanya dibatasi oleh kelas atau ruang-ruang belajar di sekolah dan kampus. Sedangkan implikasi praktis yang dapat dikerjakan oleh akademisi prodi PAI adalah dengan merumuskan dan meluruskan istilah-istilah yang digunakan oleh kependidikan kita dengan pengertian dan landasan filosofis yang benar. Kemudian merumuskan formulasi yang tepat untuk menciptakan suasana kegiatan pembelajaran yang dapat dinikmati berbagai kalangan.

Sumbangsih saran penulis terhadap majelis ilmi maiyah Padhang Mbulan berkaitan dengan pelaksanaan sistem pembelajarannya dalam membentuk learning society antara lain; Pertama, perlu diadakannya perpustakaan Padhang Mbulan yang menampung dokumentasi kegiatan maiyah dan karya tulis jama'ah maiyah sebagai tambahan referensi khazanah keilmuan. Kedua, dalam merespon intensitas ketidakhadiran Emha Ainun Nadjib (Cak Nun) dalam forum maiyah tersebut seyogyanya perlu adanya alternatif solusi pengisi acara atau narasumber yang secara kapasitas keilmuan maupun karakteristik kharisma yang sebanding atau paling tidak mendekati sosok Cak Nun tersebut. Hal tersebut dapat dilakukan dengan mengadakan kompetisi atau perlombaan dan pelatihan yang menarik guna mencari bibit-bibit Emha yang baru, seperti kompetisi debat tentang tema tertentu, lomba pembacaan puisi, atau lomba karya ilmiah ala maiyah, bisa juga dengan diadakan pelatihan atau workshop terkait tema-tema dan keilmuan penambah khazanah keilmuan Islam.

Dirasah, Vol. 2, No. 1, Februari 2019 


\section{Daftar Pustaka}

Akhmad Sudrajat, "Masyarakat Beajar" dalam http://akhmadsudrajat.wordpress.com, diakses 18 Oktober 2013.

al-Rasyidin dan Samsul Nizar, Filsafat Pendidikan Islam: Pendekatan Historis, Teoritis dan Praktis. Jakarta: Ciputat Press, 2005.

Andsisko, "Maiyah dan Ruang-Ruang Jejaring", dalam http://www.Maiyah.net/2012/04/Maiyah-dan-ruang-ruang-jejaring.html, diakses 05 Juni 2013.

Arifin, M. Kapita Selekta Pendidikan; Islam dan Umum. Jakarta: Bumi Aksara, 1995.

Darajat, Zakiyah Dkk. Metodologi Pengajaran Agama Islam. Bumi Aksara, Jakarta, 1996.

Dewan Redaksi, Ensiklopedi Islam. Jakarta: Ichtiar Baru Van Hoeven, 2001.

Dokumen Padhang Mbulan.

Furchan, Arif. Pengantar Metode penelitian Kualitatif. Surabaya: Usaha Nasional, 1992.

Hamruni, Edutainment dalam Pendidikan Islam dan Teori-teori Pembelajaran Quantum (Yogyakarta: Fakultas Tarbiyah UIN Sunan Kalijaga, 2009), 50. Iihat juga Moh. Sholeh Hamid, Metode Edutaunment. Yogyakarta: Diva Press, 2012.

Hasbullah, Kapita Selekta Pendidikan Islam. Jakarta: Grafindo Persada, 1996.

Jabrohim, Tahajjud Cinta Emha Ainun Nadjib Sebuah Kajian Sosiologi Sastra. Yogyakarta: Pustaka Pelajar, 2003.

Khozin, Jejak-jejak Pendidikan Islam di Indonesia. Bandung: Tp, 1996.

Miles, Matthew B. \& A. Michael Huberman, Analisis Data Kualitatif: Buku Sumber Tentang Metode-Metode Baru. Jakarta : Universitas Indoensia Press - UIP, 1992. 
Moleong, Lexy J. Metode Penelitian Kualitatif . Bandung: PT Remaja Rosdakarya, 2010.

Muljono, Pudji. Learning Society, Penyuluhan Dan Pembangunan Bangsa, Jurnal Penyuluhan, Vol. 3, No. 1, Maret 2007.

Nadjib, Emha Ainun. Surat Kepada Kanjeng Nabi. Bandung, Mizan: 1998.

Puslitbang Kehidupan Keagamaan, Peningkatan Peran Serta Masyarakat dalam Pendalaman Ajaran Agama Melalui Majelis Taklim. Jakarta: Badan Litbang dan Diklat Departemen Agama RI, 2007.

Redaksi Progress, "Struktur Acara Majlis Ilmu Maiyah" dalam http://www.maiyah.net/2012/04/struktur-acara-majlis-ilmu-maiyah.html, diakses 05 Juni 2013.

Sagala, Syaifullah. Konsep dan Makna Pembelajaran (Untuk Membantu Memecahkan Problematika Belajar dan Mengajar). Bandung: Alfabeta, 2007.

Sanjaya, Wina. Strategi Pembeajaran Berorientasi Standar Proses Pendidikan. Jakarta: Kencana, 2007.

Saputra, Prayogi R. Spiritual Jourey; Pemikiran \& Permenungan Emha Ainun Nadjib. Jakarta: Kompas, 2012.

Sugiyono, Metode Penelitian Kuantitatif, Kualitatif Dan Research \& Developmental. Bandung : Alfabeta, 2009.

Suparno, Sabrank. "Ujung Tombak Maiyah" daam http://www.maiyah.net, diakses 06 Juni 2013.

Suwarno, Wiji. Dasar-dasar Ilmu Pendidikan. Yogyakarta: Ar-Ruzz, 2006.

Undang-Undang Republik Indonesia Nomor 14 Tahun 2005 Tentang Guru \& Dosen Serta Undang-Undang Republik Indonesia Nomor 20 Tahun 2003 Tentang Sistem Pendidikan Nasional. Bandung: Cira Umbara, 2006.

Yin, Robert. K. Studi Kasus: Desain dan Metode. Jakarta : Rajawali Press, 2009.

Zuhairini dkk, Metodologi Pendidikan Agama. Solo: Ramadhani, 1996.

Dirasah, Vol. 2, No. 1, Februari 2019 
Copyright @ 2019 Journal Dirasah: Vol. 2, No. 1, Februari 2019, p-ISSN: 2615-0212, e-ISSN; 2621-2838

Copyright rests with the authors

Copyright of Jurnal Dirasah is the property of Jurnal Dirasah and its content may not be copied or emailed to multiple sites or posted to a listserv without the copyright holder's express written permission. However, users may print, download, or email articles for individual use.

https://ejournal.iaifa.ac.id/index.php/dirasah 